\title{
Underestimating the Challenges of Avoiding a Ghastly Future
}

\author{
Corey J. A. Bradshaw ${ }^{1,2 \star}$, Paul R. Ehrlich ${ }^{3 *}$, Andrew Beattie ${ }^{4}$, Gerardo Ceballos ${ }^{5}$, \\ Eileen Crist ${ }^{6}$, Joan Diamond ${ }^{7}$, Rodolfo Dirzo ${ }^{3}$, Anne H. Ehrlich ${ }^{3}$, John Harte ${ }^{8,9}$, \\ Mary Ellen Harte ${ }^{9}$, Graham Pyke ${ }^{4}$, Peter H. Raven ${ }^{10}$, William J. Ripple ${ }^{11}$, Frédérik Saltré ${ }^{1,2}$, \\ Christine Turnbull ${ }^{4}$, Mathis Wackernagel ${ }^{12}$ and Daniel T. Blumstein ${ }^{13,14 *}$ \\ ${ }^{1}$ Global Ecology, College of Science and Engineering, Flinders University, Adelaide, SA, Australia, ${ }^{2}$ Australian Research \\ Council Centre of Excellence for Australian Biodiversity and Heritage, EpicAustralia.org, Adelaide, SA, Australia, ${ }^{3}$ Department \\ of Biology, Stanford University, Stanford, CA, United States, ${ }^{4}$ Department of Biological Sciences, Macquarie University, \\ Sydney, NSW, Australia, ${ }^{5}$ Instituto de Ecología, Universidad Nacional Autónoma de México, Ciudad de México, Mexico, \\ ${ }^{6}$ Department of Science, Technology, and Society, Virginia Tech, Blacksburg, VA, United States, ${ }^{7}$ Millennium Alliance for \\ Humanity and the Biosphere, Department of Biology, Stanford University, Stanford, CA, United States, ${ }^{8}$ Energy and \\ Resources Group, University of California, Berkeley, Berkeley, CA, United States, ${ }^{9}$ The Rocky Mountain Biological Laboratory, \\ Crested Butte, CO, United States, ${ }^{10}$ Missouri Botanical Garden, St Louis, MO, United States, ${ }^{11}$ Department of Forest \\ Ecosystems and Society, Oregon State University, Corvallis, OR, United States, ${ }^{12}$ Global Footprint Network, Oakland, CA, \\ United States, ${ }^{13}$ Department of Ecology and Evolutionary Biology, University of California, Los Angeles, Los Angeles, CA, \\ United States, ${ }^{14} \mathrm{La}$ Kretz Hall, Institute of the Environment and Sustainability, University of California, Los Angeles, Los \\ Angeles, CA, United States
}

Dale Nimmo,

Charles Sturt University, Australia

Reviewed by:

Tanya Wyatt,

Northumbria University,

United Kingdom

Magnus Nyström,

Stockholm University, Sweden

*Correspondence:

Corey J. A. Bradshaw corey.bradshaw@flinders.edu.au

Paul R. Ehrlich pre@stanford.edu Daniel T. Blumstein marmots@ucla.edu

Specialty section: This article was submitted to

Global Biodiversity Threats,

a section of the journa

Frontiers in Conservation Science

Received: 09 October 2020 Accepted: 21 December 2020

Published: 13 January 2021

Citation:

Bradshaw CJA, Ehrlich PR, Beattie A, Ceballos G, Crist E, Diamond J,

Dirzo R, Ehrlich AH, Harte J, Harte ME, Pyke G, Raven PH, Ripple WJ, Saltré F, Turnbull C,

Wackernagel $M$ and Blumstein DT (2021) Underestimating the Challenges of Avoiding a Ghastly Future. Front. Conserv. Sci. 1:615419. doi: 10.3389/fcosc.2020.615419

We report three major and confronting environmental issues that have received little attention and require urgent action. First, we review the evidence that future environmental conditions will be far more dangerous than currently believed. The scale of the threats to the biosphere and all its lifeforms -including humanity - is in fact so great that it is difficult to grasp for even well-informed experts. Second, we ask what political or economic system, or leadership, is prepared to handle the predicted disasters, or even capable of such action. Third, this dire situation places an extraordinary responsibility on scientists to speak out candidly and accurately when engaging with government, business, and the public. We especially draw attention to the lack of appreciation of the enormous challenges to creating a sustainable future. The added stresses to human health, wealth, and well-being will perversely diminish our political capacity to mitigate the erosion of ecosystem services on which society depends. The science underlying these issues is strong, but awareness is weak. Without fully appreciating and broadcasting the scale of the problems and the enormity of the solutions required, society will fail to achieve even modest sustainability goals.

Keywords: sustainability, extinction, climate change, political will, human population, consumption

\section{INTRODUCTION}

Humanity is causing a rapid loss of biodiversity and, with it, Earth's ability to support complex life. But the mainstream is having difficulty grasping the magnitude of this loss, despite the steady erosion of the fabric of human civilization (Ceballos et al., 2015; IPBES, 2019; Convention on Biological Diversity, 2020; WWF, 2020). While suggested solutions abound (Díaz et al., 2019), the current scale of their implementation does not match the relentless progression of biodiversity loss (Cumming et al., 2006) and other existential threats tied to the continuous expansion of 
the human enterprise (Rees, 2020). Time delays between ecological deterioration and socio-economic penalties, as with climate disruption for example (IPCC, 2014), impede recognition of the magnitude of the challenge and timely counteraction needed. In addition, disciplinary specialization and insularity encourage unfamiliarity with the complex adaptive systems (Levin, 1999) in which problems and their potential solutions are embedded (Selby, 2006; Brand and Karvonen, 2007). Widespread ignorance of human behavior (Van Bavel et al., 2020) and the incremental nature of socio-political processes that plan and implement solutions further delay effective action (Shanley and López, 2009; King, 2016).

We summarize the state of the natural world in stark form here to help clarify the gravity of the human predicament. We also outline likely future trends in biodiversity decline (Díaz et al., 2019), climate disruption (Ripple et al., 2020), and human consumption and population growth to demonstrate the near certainty that these problems will worsen over the coming decades, with negative impacts for centuries to come. Finally, we discuss the ineffectiveness of current and planned actions that are attempting to address the ominous erosion of Earth's life-support system. Ours is not a call to surrender-we aim to provide leaders with a realistic "cold shower" of the state of the planet that is essential for planning to avoid a ghastly future.

\section{BIODIVERSITY LOSS}

Major changes in the biosphere are directly linked to the growth of human systems (summarized in Figure 1). While the rapid loss of species and populations differs regionally in intensity (Ceballos et al., 2015, 2017, 2020; Díaz et al., 2019), and most species have not been adequately assessed for extinction risk (Webb and Mindel, 2015), certain global trends are obvious. Since the start of agriculture around 11,000 years ago, the biomass of terrestrial vegetation has been halved (Erb et al., 2018), with a corresponding loss of $>20 \%$ of its original biodiversity (Díaz et al., 2019), together denoting that $>70 \%$ of the Earth's land surface has been altered by Homo sapiens (IPBES, 2019). There have been $>700$ documented vertebrate (Díaz et al., 2019) and $\sim 600$ plant (Humphreys et al., 2019) species extinctions over the past 500 years, with many more species clearly having gone extinct unrecorded (Tedesco et al., 2014). Population sizes of vertebrate species that have been monitored across years have declined by an average of $68 \%$ over the last five decades (WWF, 2020), with certain population clusters in extreme decline (Leung et al., 2020), thus presaging the imminent extinction of their species (Ceballos et al., 2020). Overall, perhaps 1 million species are threatened with extinction in the near future out of an estimated 7-10 million eukaryotic species on the planet (Mora et al., 2011), with around $40 \%$ of plants alone considered endangered (Antonelli et al., 2020). Today, the global biomass of wild mammals is $<25 \%$ of that estimated for the Late Pleistocene (Bar-On et al., 2018), while insects are also disappearing rapidly in many regions (Wagner, 2020; reviews in van Klink et al., 2020).

Freshwater and marine environments have also been severely damaged. Today there is $<15 \%$ of the original wetland area globally than was present 300 years ago (Davidson, 2014), and $>75 \%$ of rivers $>1,000 \mathrm{~km}$ long no longer flow freely along their entire course (Grill et al., 2019). More than two-thirds of the oceans have been compromised to some extent by human activities (Halpern et al., 2015), live coral cover on reefs has halved in $<200$ years (Frieler et al., 2013), seagrass extent has been decreasing by $10 \%$ per decade over the last century (Waycott et al., 2009; Díaz et al., 2019), kelp forests have declined by $40 \%$ (Krumhansl et al., 2016), and the biomass of large predatory fishes is now $<33 \%$ of what it was last century (Christensen et al., 2014).

With such a rapid, catastrophic loss of biodiversity, the ecosystem services it provides have also declined. These include inter alia reduced carbon sequestration (Heath et al., 2005; Lal, 2008), reduced pollination (Potts et al., 2016), soil degradation (Lal, 2015), poorer water and air quality (Smith et al., 2013), more frequent and intense flooding (Bradshaw et al., 2007; Hinkel et al., 2014) and fires (Boer et al., 2020; Bowman et al., 2020), and compromised human health (Díaz et al., 2006; Bradshaw et al., 2019). As telling indicators of how much biomass humanity has transferred from natural ecosystems to our own use, of the estimated $0.17 \mathrm{Gt}$ of living biomass of terrestrial vertebrates on Earth today, most is represented by livestock (59\%) and human beings (36\%) - only 5\% of this total biomass is made up by wild mammals, birds, reptiles, and amphibians (Bar-On et al., 2018). As of 2020, the overall material output of human endeavor exceeds the sum of all living biomass on Earth (Elhacham et al., 2020).

\section{SIXTH MASS EXTINCTION}

A mass extinction is defined as a loss of $\sim 75 \%$ of all species on the planet over a geologically short interval-generally anything <3 million years (Jablonski et al., 1994; Barnosky et al., 2011). At least five major extinction events have occurred since the Cambrian (Sodhi et al., 2009), the most recent of them 66 million years ago at the close of the Cretaceous period. The background rate of extinction since then has been 0.1 extinctions million species $^{-1}$ year $^{-1}$ (Ceballos et al., 2015), while estimates of today's extinction rate are orders of magnitude greater (Lamkin and Miller, 2016). Recorded vertebrate extinctions since the 16th century-the mere tip of the true extinction iceberg — give a rate of extinction of 1.3 species year ${ }^{-1}$, which is conservatively $>15$ times the background rate (Ceballos et al., 2015). The IUCN estimates that some $20 \%$ of all species are in danger of extinction over the next few decades, which greatly exceeds the background rate. That we are already on the path of a sixth major extinction is now scientifically undeniable (Barnosky et al., 2011; Ceballos et al., 2015, 2017).

\section{ECOLOGICAL OVERSHOOT: POPULATION SIZE AND OVERCONSUMPTION}

The global human population has approximately doubled since 1970 , reaching nearly 7.8 billion people today (prb.org). While some countries have stopped growing and even declined in size, 


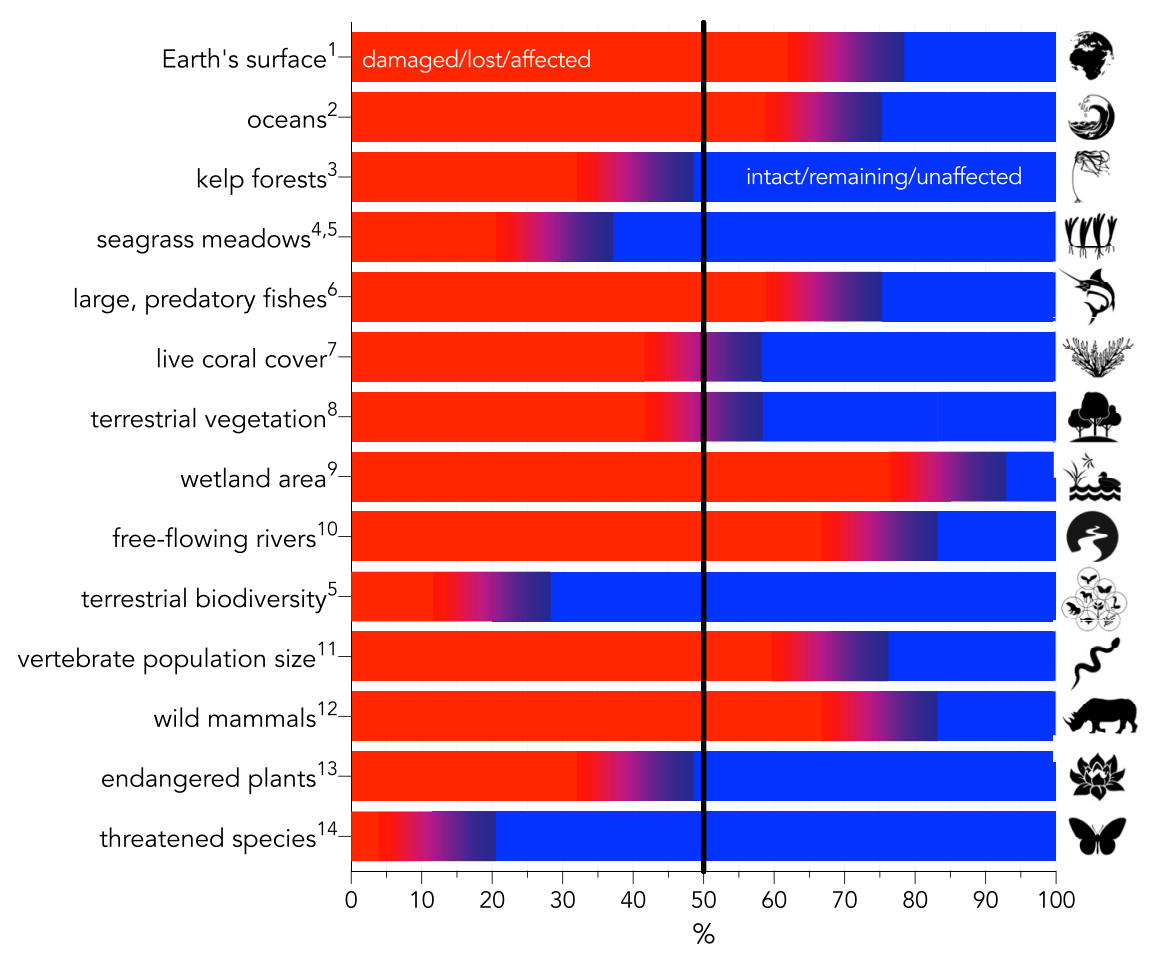

FIGURE 1 | Summary of major environmental-change categories expressed as a percentage change relative to the baseline given in the text. Red indicates the percentage of the category that is damaged, lost, or otherwise affected, whereas blue indicates the percentage that is intact, remaining, or otherwise unaffected. Superscript numbers indicate the following references: ${ }^{1}$ IPBES, 2019; ${ }^{2}$ Halpern et al., 2015; ${ }^{3}$ Krumhansl et al., 2016 ; ${ }^{4}$ Waycott et al., 2009; ${ }^{5}$ Díaz et al., 2019; ${ }^{6}$ Christensen et al., 2014; ${ }^{7}$ Frieler et al., 2013; ${ }^{8}$ Erb et al., 2018; ${ }^{9}$ Davidson, 2014; ${ }^{10}$ Grill et al., 2019; ${ }^{11}$ WWF, 2020; ${ }^{12}$ Bar-On et al., 2018; ${ }^{13}$ Antonelli et al., 2020; ${ }^{14}$ Mora et al., 2011.

world average fertility continues to be above replacement $(2.3$ children woman ${ }^{-1}$ ), with an average of 4.8 children woman ${ }^{-1}$ in Sub-Saharan Africa and fertilities $>4$ children woman ${ }^{-1}$ in many other countries (e.g., Afghanistan, Yemen, Timor-Leste). The 1.1 billion people today in Sub-Saharan Africa-a region expected to experience particularly harsh repercussions from climate change (Serdeczny et al., 2017) —is projected to double over the next 30 years. By 2050, the world population will likely grow to $\sim 9.9$ billion (prb.org), with growth projected by many to continue until well into the next century (Bradshaw and Brook, 2014; Gerland et al., 2014), although more recent estimates predict a peak toward the end of this century (Vollset et al., 2020).

Large population size and continued growth are implicated in many societal problems. The impact of population growth, combined with an imperfect distribution of resources, leads to massive food insecurity. By some estimates, 700-800 million people are starving and 1-2 billion are micronutrientmalnourished and unable to function fully, with prospects of many more food problems in the near future (Ehrlich and Harte, 2015a,b). Large populations and their continued growth are also drivers of soil degradation and biodiversity loss (Pimm et al., 2014). More people means that more synthetic compounds and dangerous throw-away plastics (Vethaak and Leslie, 2016) are manufactured, many of which add to the growing toxification of the Earth (Cribb, 2014). It also increases chances of pandemics
(Daily and Ehrlich, 1996b) that fuel ever-more desperate hunts for scarce resources (Klare, 2012). Population growth is also a factor in many social ills, from crowding and joblessness, to deteriorating infrastructure and bad governance (Harte, 2007). There is mounting evidence that when populations are large and growing fast, they can be the sparks for both internal and international conflicts that lead to war (Klare, 2001; Toon et al., 2007). The multiple, interacting causes of civil war in particular are varied, including poverty, inequality, weak institutions, political grievance, ethnic divisions, and environmental stressors such as drought, deforestation, and land degradation (HomerDixon, 1991, 1999; Collier and Hoeer, 1998; Hauge and llingsen, 1998; Fearon and Laitin, 2003; Brückner, 2010; Acemoglu et al., 2017). Population growth itself can even increase the probability of military involvement in conflicts (Tir and Diehl, 1998). Countries with higher population growth rates experienced more social conflict since the Second World War (Acemoglu et al., 2017). In that study, an approximate doubling of a country's population caused about four additional years of full-blown civil war or low-intensity conflict in the 1980s relative to the 1940-1950s, even after controlling for a country's income-level, independence, and age structure.

Simultaneous with population growth, humanity's consumption as a fraction of Earth's regenerative capacity has grown from $~ 73 \%$ in 1960 to $170 \%$ in 2016 (Lin et al., 2018), 
with substantially greater per-person consumption in countries with highest income. With COVID-19, this overshoot dropped to $56 \%$ above Earth's regenerative capacity, which means that between January and August 2020, humanity consumed as much as Earth can renew in the entire year (overshootday.org). While inequality among people and countries remains staggering, the global middle class has grown rapidly and exceeded half the human population by 2018 (Kharas and Hamel, 2018). Over $70 \%$ of all people currently live in countries that run a biocapacity deficit while also having less than world-average income, excluding them from compensating their biocapacity deficit through purchases (Wackernagel et al., 2019) and eroding future resilience via reduced food security (Ehrlich and Harte, 2015b). The consumption rates of high-income countries continue to be substantially higher than low-income countries, with many of the latter even experiencing declines in per-capita footprint (Dasgupta and Ehrlich, 2013; Wackernagel et al., 2019).

This massive ecological overshoot is largely enabled by the increasing use of fossil fuels. These convenient fuels have allowed us to decouple human demand from biological regeneration: $85 \%$ of commercial energy, $65 \%$ of fibers, and most plastics are now produced from fossil fuels. Also, food production depends on fossil-fuel input, with every unit of food energy produced requiring a multiple in fossil-fuel energy (e.g., $3 \times$ for high-consuming countries like Canada, Australia, USA, and China; overshootday.org). This, coupled with increasing consumption of carbon-intensive meat (Ripple et al., 2014) congruent with the rising middle class, has exploded the global carbon footprint of agriculture. While climate change demands a full exit from fossil-fuel use well before 2050, pressures on the biosphere are likely to mount prior to decarbonization as humanity brings energy alternatives online. Consumption and biodiversity challenges will also be amplified by the enormous physical inertia of all large "stocks" that shape current trends: built infrastructure, energy systems, and human populations.

It is therefore also inevitable that aggregate consumption will increase at least into the near future, especially as affluence and population continue to grow in tandem (Wiedmann et al., 2020). Even if major catastrophes occur during this interval, they would unlikely affect the population trajectory until well into the 22nd Century (Bradshaw and Brook, 2014). Although population-connected climate change (Wynes and Nicholas, 2017) will worsen human mortality (Mora et al., 2017; Parks et al., 2020), morbidity (Patz et al., 2005; Díaz et al., 2006; Peng et al., 2011), development (Barreca and Schaller, 2020), cognition (Jacobson et al., 2019), agricultural yields (Verdin et al., 2005; Schmidhuber and Tubiello, 2007; Brown and Funk, 2008; Gaupp et al., 2020), and conflicts (Boas, 2015), there is no way-ethically or otherwise (barring extreme and unprecedented increases in human mortality) - to avoid rising human numbers and the accompanying overconsumption. That said, instituting humanrights policies to lower fertility and reining in consumption patterns could diminish the impacts of these phenomena (Rees, 2020).

\section{FAILED INTERNATIONAL GOALS AND PROSPECTS FOR THE FUTURE}

Stopping biodiversity loss is nowhere close to the top of any country's priorities, trailing far behind other concerns such as employment, healthcare, economic growth, or currency stability. It is therefore no surprise that none of the Aichi Biodiversity Targets for 2020 set at the Convention on Biological Diversity's (CBD.int) 2010 conference was met (Secretariat of the Convention on Biological Diversity, 2020). Even had they been met, they would have still fallen short of realizing any substantive reductions in extinction rate. More broadly, most of the naturerelated United Nations Sustainable Development Goals (SDGs) (e.g., SDGs 6, 13-15) are also on track for failure (Wackernagel et al., 2017; Díaz et al., 2019; Messerli et al., 2019), largely because most SDGs have not adequately incorporated their interdependencies with other socio-economic factors (Bradshaw and Di Minin, 2019; Bradshaw et al., 2019; Messerli et al., 2019). Therefore, the apparent paradox of high and rising average standard of living despite a mounting environmental toll has come at a great cost to the stability of humanity's mediumand long-term life-support system. In other words, humanity is running an ecological Ponzi scheme in which society robs nature and future generations to pay for boosting incomes in the short term (Ehrlich et al., 2012). Even the World Economic Forum, which is captive of dangerous greenwashing propaganda (Bakan, 2020), now recognizes biodiversity loss as one of the top threats to the global economy (World Economic Forum, 2020).

The emergence of a long-predicted pandemic (Daily and Ehrlich, 1996a), likely related to biodiversity loss, poignantly exemplifies how that imbalance is degrading both human health and wealth (Austin, 2020; Dobson et al., 2020; Roe et al., 2020). With three-quarters of new infectious diseases resulting from human-animal interactions, environmental degradation via climate change, deforestation, intensive farming, bushmeat hunting, and an exploding wildlife trade mean that the opportunities for pathogen-transferring interactions are high (Austin, 2020; Daszak et al., 2020). That much of this degradation is occurring in Biodiversity Hotspots where pathogen diversity is also highest (Keesing et al., 2010), but where institutional capacity is weakest, further increases the risk of pathogen release and spread (Austin, 2020; Schmeller et al., 2020).

\section{CLIMATE DISRUPTION}

The dangerous effects of climate change are much more evident to people than those of biodiversity loss (Legagneux et al., 2018), but society is still finding it difficult to deal with them effectively. Civilization has already exceeded a global warming of $\sim 1.0^{\circ} \mathrm{C}$ above pre-industrial conditions, and is on track to cause at least a $1.5^{\circ} \mathrm{C}$ warming between 2030 and 2052 (IPCC, 2018). In fact, today's greenhouse-gas concentration is $>500$ ppm $\mathrm{CO}_{2}$-e (Butler and Montzka, 2020), while according to the IPCC, $450 \mathrm{ppm} \mathrm{CO}_{2}$-e would give Earth a mere $66 \%$ chance of not exceeding a $2^{\circ} \mathrm{C}$ warming (IPCC, 2014). Greenhouse-gas concentration will continue to increase (via positive feedbacks 
such as melting permafrost and the release of stored methane) (Burke et al., 2018), resulting in further delay of temperaturereducing responses even if humanity stops using fossil fuels entirely well before 2030 (Steffen et al., 2018).

Human alteration of the climate has become globally detectable in any single day's weather (Sippel et al., 2020). In fact, the world's climate has matched or exceeded previous predictions (Brysse et al., 2013), possibly because of the IPCC's reliance on averages from several models (Herger et al., 2018) and the language of political conservativeness inherent in policy recommendations seeking multinational consensus (HerrandoPérez et al., 2019). However, the latest climate models (CMIP6) show greater future warming than previously predicted (Forster et al., 2020), even if society tracks the needed lower-emissions pathway over the coming decades. Nations have in general not met the goals of the 5 year-old Paris Agreement (United Nations, 2016), and while global awareness and concern have risen, and scientists have proposed major transformative change (in energy production, pollution reduction, custodianship of nature, food production, economics, population policies, etc.), an effective international response has yet to emerge (Ripple et al., 2020). Even assuming that all signatories do, in fact, manage to ratify their commitments (a doubtful prospect), expected warming would still reach $2.6-3.1^{\circ} \mathrm{C}$ by 2100 (Rogelj et al., 2016) unless large, additional commitments are made and fulfilled. Without such commitments, the projected rise of Earth's temperature will be catastrophic for biodiversity (Urban, 2015; Steffen et al., 2018; Strona and Bradshaw, 2018) and humanity (Smith et al., 2016).

Regarding international climate-change accords, the Paris Agreement (United Nations, 2016) set the $1.5-2^{\circ} \mathrm{C}$ target unanimously. But since then, progress to propose, let alone follow, (voluntary) "intended national determined contributions" for post-2020 climate action have been utterly inadequate.

\section{POLITICAL IMPOTENCE}

If most of the world's population truly understood and appreciated the magnitude of the crises we summarize here, and the inevitability of worsening conditions, one could logically expect positive changes in politics and policies to match the gravity of the existential threats. But the opposite is unfolding. The rise of right-wing populist leaders is associated with anti-environment agendas as seen recently for example in Brazil (Nature, 2018), the USA (Hejny, 2018), and Australia (Burck et al., 2019). Large differences in income, wealth, and consumption among people and even among countries render it difficult to make any policy global in its execution or effect.

A central concept in ecology is density feedback (HerrandoPérez et al., 2012) - as a population approaches its environmental carrying capacity, average individual fitness declines (Brook and Bradshaw, 2006). This tends to push populations toward an instantaneous expression of carrying capacity that slows or reverses population growth. But for most of history, human ingenuity has inflated the natural environment's carrying capacity for us by developing new ways to increase food production (Hopfenberg, 2003), expand wildlife exploitation, and enhance the availability of other resources. This inflation has involved modifying temperature via shelter, clothing, and microclimate control, transporting goods from remote locations, and generally reducing the probability of death or injury through community infrastructure and services (Cohen, 1995). But with the availability of fossil fuels, our species has pushed its consumption of nature's goods and services much farther beyond long-term carrying capacity (or more precisely, the planet's biocapacity), making the readjustment from overshoot that is inevitable far more catastrophic if not managed carefully (Nyström et al., 2019). A growing human population will only exacerbate this, leading to greater competition for an everdwindling resource pool. The corollaries are many: continued reduction of environmental intactness (Bradshaw et al., 2010; Bradshaw and Di Minin, 2019), reduced child health (especially in low-income nations) (Bradshaw et al., 2019), increased food demand exacerbating environmental degradation via agrointensification (Crist et al., 2017), vaster and possibly catastrophic effects of global toxification (Cribb, 2014; Swan and Colino, 2021), greater expression of social pathologies (Levy and Herzog, 1974) including violence exacerbated by climate change and environmental degradation itself (Agnew, 2013; White, 2017, 2019), more terrorism (Coccia, 2018), and an economic system even more prone to sequester the remaining wealth among fewer individuals (Kus, 2016; Piketty, 2020) much like how cropland expansion since the early 1990s has disproportionately concentrated wealth among the super-rich (Ceddia, 2020). The predominant paradigm is still one of pegging "environment" against "economy"; yet in reality, the choice is between exiting overshoot by design or disaster-because exiting overshoot is inevitable one way or another.

Given these misconceptions and entrenched interests, the continued rise of extreme ideologies is likely, which in turn limits the capacity of making prudent, long-term decisions, thus potentially accelerating a vicious cycle of global ecological deterioration and its penalties. Even the USA's much-touted New Green Deal (U. S. House of Representatives, 2019) has in fact exacerbated the country's political polarization (Gustafson et al., 2019), mainly because of the weaponization of 'environmentalism' as a political ideology rather than being viewed as a universal mode of self-preservation and planetary protection that ought to transcend political tribalism. Indeed, environmental protest groups are being labeled as "terrorists" in many countries (Hudson, 2020). Further, the severity of the commitments required for any country to achieve meaningful reductions in consumption and emissions will inevitably lead to public backlash and further ideological entrenchments, mainly because the threat of potential short-term sacrifices is seen as politically inopportune. Even though climate change alone will incur a vast economic burden (Burke et al., 2015; Carleton and Hsiang, 2016; Auffhammer, 2018) possibly leading to war (nuclear, or otherwise) at a global scale (Klare, 2020), most of the world's economies are predicated on the political idea that meaningful counteraction now is too costly to be politically palatable. Combined with financed disinformation campaigns in a bid to protect short-term profits (Oreskes and Conway, 2010; 
Mayer, 2016; Bakan, 2020), it is doubtful that any needed shift in economic investments of sufficient scale will be made in time.

While uncertain and prone to fluctuate according to unpredictable social and policy trends (Boas et al., 2019; McLeman, 2019; Nature Climate Change, 2019), climate change and other environmental pressures will trigger more mass migration over the coming decades (McLeman, 2019), with an estimated 25 million to 1 billion environmental migrants expected by 2050 (Brown, 2008). Because international law does not yet legally recognize such "environmental migrants" as refugees (United Nations University, 2015) (although this is likely to change) (Lyons, 2020), we fear that a rising tide of refugees will reduce, not increase, international cooperation in ways that will further weaken our capacity to mitigate the crisis.

\section{CHANGING THE RULES OF THE GAME}

While it is neither our intention nor capacity in this short Perspective to delve into the complexities and details of possible solutions to the human predicament, there is no shortage of evidence-based literature proposing ways to change human behavior for the benefit of all extant life. The remaining questions are less about what to do, and more about how, stimulating the genesis of many organizations devoted to these pursuits (e.g., ipbes.org, goodanthropocenes.net, overshootday.org, mahb.stanford.edu, populationmatters.org, clubofrome.org, steadystate.org, to name a few). The gravity of the situation requires fundamental changes to global capitalism, education, and equality, which include inter alia the abolition of perpetual economic growth, properly pricing externalities, a rapid exit from fossil-fuel use, strict regulation of markets and property acquisition, reigning in corporate lobbying, and the empowerment of women. These choices will necessarily entail difficult conversations about population growth and the necessity of dwindling but more equitable standards of living.

\section{CONCLUSIONS}

We have summarized predictions of a ghastly future of mass extinction, declining health, and climate-disruption upheavals (including looming massive migrations) and resource conflicts this century. Yet, our goal is not to present a fatalist perspective,

\section{REFERENCES}

Acemoglu, D., Fergusson, L., and Johnson, S. (2017). "Population and civil war," in National Bureau of Economic Research Working Paper Series Working Paper No. 23322 (Cambridge, MA), 1-49. doi: 10.3386/w23322

Agnew, R. (2013). "The ordinary acts that contribute to ecocide: a criminological analysis," in Routledge International Handbook of Green Criminology, eds. N. South and A. Brisman (Abingdon: Routledge), 58-72.

Antonelli, A., Fry, C., Smith, R. J., Simmonds, M. S. J., Kersey, P. J., Pritchard, H. W., et al. (2020). State of the World's Plants and Fungi 2020. Kew: Royal Botanic Gardens.

Auffhammer, M. (2018). Quantifying economic damages from climate change. J. Econ. Persp. 32, 33-52. doi: 10.1257/jep.32.4.33 because there are many examples of successful interventions to prevent extinctions, restore ecosystems, and encourage more sustainable economic activity at both local and regional scales. Instead, we contend that only a realistic appreciation of the colossal challenges facing the international community might allow it to chart a less-ravaged future. While there have been more recent calls for the scientific community in particular to be more vocal about their warnings to humanity (Ripple et al., 2017; Cavicchioli et al., 2019; Gardner and Wordley, 2019), these have been insufficiently foreboding to match the scale of the crisis. Given the existence of a human "optimism bias" that triggers some to underestimate the severity of a crisis and ignore expert warnings, a good communication strategy must ideally undercut this bias without inducing disproportionate feelings of fear and despair (Pyke, 2017; Van Bavel et al., 2020). It is therefore incumbent on experts in any discipline that deals with the future of the biosphere and human well-being to eschew reticence, avoid sugar-coating the overwhelming challenges ahead and "tell it like it is." Anything else is misleading at best, or negligent and potentially lethal for the human enterprise at worst.

\section{DATA AVAILABILITY STATEMENT}

The original contributions presented in the study are included in the article/supplementary material, further inquiries can be directed to the corresponding author/s.

\section{AUTHOR CONTRIBUTIONS}

CJAB, DTB, and PRE designed the concept and wrote the article, with contributions from AB, GC, EC, JD, RD, AHE, JH, $\mathrm{MEH}, \mathrm{GP}, \mathrm{PHR}, \mathrm{WJR}, \mathrm{FS}, \mathrm{CT}$, and MW. CJAB prepared the figure. All authors contributed to the article and approved the submitted version.

\section{FUNDING}

We thank the Rockefeller Foundation for Bellagio Writer's Fellowships to CJAB and PRE. Supported in part by the Australian Research Council Centre of Excellence for Australian Biodiversity and Heritage (CE170100015).
Austin, K. F. (2020). Degradation and disease: ecologically unequal exchanges cultivate emerging pandemics. World Dev. 137:105163. doi: 10.1016/j.worlddev.2020.105163

Bakan, J. (2020). The New Corporation: How "Good" Corporations are Bad for Democracy. New York, NY: Vintage.

Barnosky, A. D., Matzke, N., Tomiya, S., Wogan, G. O. U., Swartz, B., Quental, T. B., et al. (2011). Has the Earth's sixth mass extinction already arrived? Nature 471, 51-57. doi: 10.1038/nature 09678

Bar-On, Y. M., Phillips, R., and Milo, R. (2018). The biomass distribution on Earth. Proc. Natl. Acad. Sci. U.S.A. 115:6506-6511. doi: 10.1073/pnas.1711842115

Barreca, A., and Schaller, J. (2020). The impact of high ambient temperatures on delivery timing and gestational lengths. Nat. Clim. Change 10, 77-82. doi: 10.1038/s41558-019-0632-4 
Boas, I. (2015). Climate Migration and Security. New York, NY: Routledge. doi: $10.4324 / 9781315749228$

Boas, I., Farbotko, C., Adams, H., Sterly, H., Bush, S., van der Geest, K., et al. (2019). Climate migration myths. Nat. Clim. Change 9, 901-903. doi: 10.1038/s41558-019-0633-3

Boer, M. M., Resco de Dios, V., and Bradstock, R. A. (2020). Unprecedented burn area of Australian mega forest fires. Nat. Clim. Change 10, 171-172. doi: 10.1038/s41558-020-0716-1

Bowman, D. M. J. S., Kolden, C. A., Abatzoglou, J. T., Johnston, F. H., van der Werf, G. R., and Flannigan, M. (2020). Vegetation fires in the Anthropocene. Nat. Rev. Earth Environ. 1, 500-515. doi: 10.1038/s43017-020-0085-3

Bradshaw, C. J. A., and Brook, B. W. (2014). Human population reduction is not a quick fix for environmental problems. Proc. Natl. Acad. Sci. U.S.A. 111, 16610-16615. doi: 10.1073/pnas.1410465111

Bradshaw, C. J. A., and Di Minin, E. (2019). Socio-economic predictors of environmental performance among African nations. Sci. Rep. 9:9306. doi: 10.1038/s41598-019-45762-3

Bradshaw, C. J. A., Giam, X., and Sodhi, N. S. (2010). Evaluating the relative environmental impact of countries. PLoS ONE 5:e10440. doi: 10.1371/journal.pone.0010440

Bradshaw, C. J. A., Otto, S. P., Annamalay, A. A., Heft-Neal, S., Wagner, Z., Le Souëf, P. N., et al. (2019). Testing the socioeconomic and environmental determinants of better child-health outcomes in Africa: a cross-sectional study among nations. BMJ Open 9:e029968. doi: 10.1136/bmjopen-2019-029968

Bradshaw, C. J. A., Sodhi, N. S., Peh, K. S. H., and Brook, B. W. (2007). Global evidence that deforestation amplifies flood risk and severity in the developing world. Glob. Change Biol. 13, 2379-2395. doi: 10.1111/j.1365-2486.2007.01446.x

Brand, R., and Karvonen, A. (2007). The ecosystem of expertise: complementary knowledges for sustainable development. Sustain. Sci. Pract. Pol. 3, 21-31. doi: 10.1080/15487733.2007.11907989

Brook, B. W., and Bradshaw, C. J. A. (2006). Strength of evidence for density dependence in abundance time series of 1198 species. Ecology 87, 1445-1451. doi: 10.1890/0012-9658(2006)871445:SOEFDD2.0.CO;2

Brown, M. E., and Funk, C. C. (2008). Food security under climate change. Science 319:580. doi: 10.1126/science.1154102

Brown, O. (2008). "Migration and climate change," in IOM Migration Research Series, ed Brown, O., (Geneva: International Organization for Migration), 1-61. doi: $10.18356 / 26 \mathrm{de} 4416$-en

Brückner, M. (2010). Population size and civil conflict risk: is there a causal link? Econ. J. 120, 535-550. doi: 10.1111/j.1468-0297.2010.02352.x

Brysse, K., Oreskes, N., O’Reilly, J., and Oppenheimer, M. (2013). Climate change prediction: erring on the side of least drama? Global Environ. Change 23, 327-337. doi: 10.1016/j.gloenvcha.2012.10.008

Burck, J., Hagen, U., HÃúhne, N., Nascimento, L., and Bals, C. (2019). Climate Change Performance Index. Bonn: Germanwatch, NewClimate Institute and Climate Action Network.

Burke, E. J., Chadburn, S. E., Huntingford, C., and Jones, C. D. (2018). $\mathrm{CO}_{2}$ loss by permafrost thawing implies additional emissions reductions to limit warming to 1.5 or $2{ }^{\circ} \mathrm{C}$. Environ. Res. Lett. 13:024024. doi: 10.1088/1748-9326/aaal38

Burke, M., Hsiang, S. M., and Miguel, E. (2015). Global non-linear effect of temperature on economic production. Nature 527, 235-239. doi: $10.1038 /$ nature 15725

Butler, J. H., and Montzka, S. A. (2020). The NOAA Annual Greenhouse Gas Index (AGGI). Boulder, CO: National Oceanic and Atmospheric Administration, Global Monitoring Laboratory, Earth System Research Laboratories.

Carleton, T. A., and Hsiang, S. M. (2016). Social and economic impacts of climate. Science 353:aad9837. doi: 10.1126/science.aad9837

Cavicchioli, R., Ripple, W. J., Timmis, K. N., Azam, F., Bakken, L. R., Baylis, M., et al. (2019). Scientists' warning to humanity: microorganisms and climate change. Nat. Rev. Microbiol. 17, 569-586. doi: 10.1038/s41579-019-0222-5

Ceballos, G., Ehrlich, P. R., Barnosky, A. D., García, A., Pringle, R. M., and Palmer, T. M. (2015). Accelerated modern human-induced species losses: entering the sixth mass extinction. Sci. Adv. 1:e1400253. doi: 10.1126/sciadv.1400253

Ceballos, G., Ehrlich, P. R., and Dirzo, R. (2017). Biological annihilation via the ongoing sixth mass extinction signaled by vertebrate population losses and declines. Proc. Natl. Acad. Sci. U.S.A. 114, E6089-E6096. doi: $10.1073 /$ pnas. 1704949114
Ceballos, G., Ehrlich, P. R., and Raven, P. H. (2020). Vertebrates on the brink as indicators of biological annihilation and the sixth mass extinction. Proc. Natl. Acad. Sci. U.S.A. 117, 13596-13602. doi: 10.1073/pnas.1922686117

Ceddia, M. G. (2020). The super-rich and cropland expansion via direct investments in agriculture. Nat. Sustain. 3, 312-318. doi: 10.1038/s41893-020-0480-2

Christensen, V., Coll, M., Piroddi, C., Steenbeek, J., Buszowski, J., and Pauly, D. (2014). A century of fish biomass decline in the ocean. Mar. Ecol. Prog. Ser. 512, 155-166. doi: 10.3354/meps10946

Coccia, M. (2018). Growth rate of population associated with high terrorism incidents in society. J. Econ. Bibliogr. 5, 142-158. doi: 10.1453/jeb.v5i3.1743

Cohen, J. E. (1995). Population growth and earth's human carrying capacity. Science 269, 341-346. doi: 10.1126/science.7618100

Collier, P., and Hoeer, A. (1998). On economic causes of civil war. Oxf. Econ. Pap. 50, 563-573. doi: 10.1093/oep/50.4.563

Convention on Biological Diversity (2020). Global Biodiversity Outlook. Montréal, QC: Secretariat of the Convention on Biological Diversity.

Cribb, J. (2014). Poisoned Planet. Crows Nest, NSW: Allen \& Unwin.

Crist, E., Mora, C., and Engelman, R. (2017). The interaction of human population, food production, and biodiversity protection. Science 356, 260-264 doi: 10.1126/science.aal2011

Cumming, G. S., Cumming, D. H. M., and Redman, C. L. (2006). Scale mismatches in social-ecological systems: causes, consequences, and solutions. Ecol. Soc. 11:14. doi: 10.5751/ES-01569-110114

Daily, G. C., and Ehrlich, P. R. (1996a). Global change and human susceptibility to disease. Ann. Rev. Energ. Environ. 21, 125-144. doi: 10.1146/annurev.energy.21.1.125

Daily, G. C., and Ehrlich, P. R. (1996b). Impacts of development and global change on the epidemiological environment. Environ. Dev. Econ. 1, 309-344. doi: 10.1017/S1355770X00000656

Dasgupta, P. S., and Ehrlich, P. R. (2013). Pervasive externalities at the population, consumption, and environment nexus. Science 340, 324-328. doi: $10.1126 /$ science. 1224664

Daszak, P., das Neves, C., Amuasi, J., Hayman, D., Kuiken, T., Roche, B., et al. (2020). Workshop Report on Biodiversity and Pandemics of the Intergovernmental Platform on Biodiversity and Ecosystem Services. Bonn: IPBES Secretariat.

Davidson, N. C. (2014). How much wetland has the world lost? Long-term and recent trends in global wetland area. Mar. Freshw. Res. 65, 934-941. doi: 10.1071/MF14173

Díaz, S., Fargione, J., Chapin, F. S., and Tilman, D. (2006). Biodiversity loss threatens human well-being. PLoS Biol. 4:e277. doi: 10.1371/journal.pbio.0040277

Díaz, S., Settele, J., Brondízio, E. S., Ngo, H. T., Agard, J., Arneth, A., et al. (2019). Pervasive human-driven decline of life on Earth points to the need for transformative change. Science 366:eaax3100. doi: 10.1126/science.aax3100

Dobson, A. P., Pimm, S. L., Hannah, L., Kaufman, L., Ahumada, J. A., Ando, A. W., et al. (2020). Ecology and economics for pandemic prevention. Science 369, 379-381. doi: 10.1126/science.abc3189

Ehrlich, P. R., and Harte, J. (2015a). Food security requires a new revolution. Int. J. Environ. Stud. 72, 908-920. doi: 10.1080/00207233.2015.1067468

Ehrlich, P. R., and Harte, J. (2015b). To feed the world in 2050 will require a global revolution. Proc. Natl. Acad. Sci. U.S.A. 112, 14743-14744. doi: $10.1073 /$ pnas. 1519841112

Ehrlich, P. R., Kareiva, P. M., and Daily, G. C. (2012). Securing natural capital and expanding equity to rescale civilization. Nature 486, 68-73. doi: $10.1038 /$ nature11157

Elhacham, E., Ben-Uri, L., Grozovski, J., Bar-On, Y. M., and Milo, R. (2020). Global human-made mass exceeds all living biomass. Nature 588, 442-444 doi: 10.1038/s41586-020-3010-5

Erb, K.-H., Kastner, T., Plutzar, C., Bais, A. L. S., Carvalhais, N., Fetzel, T., et al. (2018). Unexpectedly large impact of forest management and grazing on global vegetation biomass. Nature 553, 73-76. doi: 10.1038/nature25138

Fearon, J. D., and Laitin, D. D. (2003). Ethnicity, insurgency, and civil war. Am. Pol. Sci. Rev. 97, 75-90. doi: 10.1017/S0003055403000534

Forster, P. M., Maycock, A. C., McKenna, C. M., and Smith, C. J. (2020). Latest climate models confirm need for urgent mitigation. Nat. Clim. Change 10, 7-10. doi: $10.1038 / s 41558-019-0660-0$ 
Frieler, K., Meinshausen, M., Golly, A., Mengel, M., Lebek, K., Donner, S. D., et al. (2013). Limiting global warming to $2^{\circ} \mathrm{C}$ is unlikely to save most coral reefs. Nat. Clim. Change 3, 165-170. doi: 10.1038/nclimate1674

Gardner, C. J., and Wordley, C. F. R. (2019). Scientists must act on our own warnings to humanity. Nat. Ecol. Evol. 3, 1271-1272. doi: 10.1038/s41559-019-0979-y

Gaupp, F., Hall, J., Hochrainer-Stigler, S., and Dadson, S. (2020). Changing risks of simultaneous global breadbasket failure. Nat. Clim. Change 10, 54-57. doi: 10.1038/s41558-019-0600-Z

Gerland, P., Raftery, A. E., Ševčíková, H., Li, N., Gu, D., Spoorenberg, T., et al. (2014). World population stabilization unlikely this century. Science 346, 234-237. doi: 10.1126/science. 1257469

Grill, G., Lehner, B., Thieme, M., Geenen, B., Tickner, D., Antonelli, F., et al. (2019). Mapping the world's free-flowing rivers. Nature 569, 215-221. doi: 10.1038/s41586-019-1111-9

Gustafson, A., Rosenthal, S. A., Ballew, M. T., Goldberg, M. H., Bergquist, P., Kotcher, J. E., et al. (2019). The development of partisan polarization over the Green New Deal. Nat. Clim. Change 9, 940-944. doi: 10.1038/s41558-019-0621-7

Halpern, B. S., Longo, C., Lowndes, J. S. S., Best, B. D., Frazier, M., Katona, S. K., et al. (2015). Patterns and emerging trends in global ocean health. PLoS ONE 10:e0117863. doi: 10.1371/journal.pone.0117863

Harte, J. (2007). Human population as a dynamic factor in environmental degradation. Pop. Env. 28, 223-236. doi: 10.1007/s11111-007-0048-3

Hauge, W., and llingsen, T. (1998). Beyond environmental scarcity: causal pathways to conflict. J. Peace Res. 35, 299-317. doi: $10.1177 / 0022343398035003003$

Heath, J., Ayres, E., Possell, M., Bardgett, R. D., Black, H. I. J., Grant, H., et al. (2005). Rising atmospheric $\mathrm{CO}_{2}$ reduces sequestration of root-derived soil carbon. Science 309, 1711-1713. doi: 10.1126/science. 1110700

Hejny, J. (2018). The Trump Administration and environmental policy: Reagan redux? J. Env. Stud. Sci. 8, 197-211. doi: 10.1007/s13412-0180470-0

Herger, N., Abramowitz, G., Knutti, R., Angélil, O., Lehmann, K., and Sanderson, B. M. (2018). Selecting a climate model subset to optimise key ensemble properties. Earth Syst. Dyn. 9, 135-151. doi: 10.5194/esd-9-135-2018

Herrando-Pérez, S., Bradshaw, C. J. A., Lewandowsky, S., and Vieites, D. R. (2019). Statistical language backs conservatism in climate-change assessments. BioScience 69, 209-219. doi: 10.1093/biosci/biz004

Herrando-Pérez, S., Delean, S., Brook, B. W., and Bradshaw, C. J. A. (2012). Density dependence: an ecological Tower of Babel. Oecologia 170, 585-603. doi: 10.1007/s00442-012-2347-3

Hinkel, J., Lincke, D., Vafeidis, A. T., Perrette, M., Nicholls, R. J., Tol, R. S. J., et al. (2014). Coastal flood damage and adaptation costs under 21 st century sea-level rise. Proc. Natl. Acad. Sci. U.S.A. 111, 3292-3297. doi: 10.1073/pnas.1222469111

Homer-Dixon, T. F. (1991). On the threshold: environmental changes as causes of acute conflict. Int. Secur. 2, 76-116. doi: 10.2307/2539061

Homer-Dixon, T. F. (1999). Environment, Scarcity, and Violence. Princeton, NJ: Princeton University Press.

Hopfenberg, R. (2003). Human carrying capacity is determined by food availability. Pop. Env. 25, 109-117. doi: 10.1023/B:POEN.0000015560.69479.c1

Hudson, M. (2020). Extinction Rebellion: 'terror threat' is a wake-up call for how the state treats environmental activism. The Conversation. Available online at: http://theconversation.com/extinction-rebellion-terror-threat-is-a-wakeup-call-for-how-the-state-treats-environmental-activism-129804 (accessed December 28, 2020).

Humphreys, A. M., Govaerts, R., Ficinski, S. Z., Nic Lughadha, E., and Vorontsova, M. S. (2019). Global dataset shows geography and life form predict modern plant extinction and rediscovery. Nat. Ecol. Evol. 3, 1043-1047. doi: 10.1038/s41559-019-0906-2

IPBES (2019). Global Assessment Report on Biodiversity and Ecosystem Services. Paris: IPBES Secretariat.

IPCC (2014). "Climate Change 2014: Synthesis Report. Contribution of Working Groups I, II and III to the Fifth Assessment Report of the Intergovernmental Panel on Climate Change", eds Core Writing Team, R. K. Pachauri, and L. A. Meyer. (Geneva: Intergovernmental Panel on Climate Change), 1-24.
IPCC (2018). “Global Warming of $1.5^{\circ} \mathrm{C}$. Summary for Policymakers," eds V. Masson-Delmotte, P. Zhai, H.-O. Pörtner, D. Roberts, J. Skea, P. R. Shukla, et al. (Geneva: Intergovernmental Panel on Climate Change), 1-24.

Jablonski, D., Chaloner, W. G., Lawton, J. H., and May, R. M. (1994). Extinctions in the fossil record. Phil. Trans. R. Soc. B 344, 11-17. doi: 10.1098/rstb.1994.0045

Jacobson, T. A., Kler, J. S., Hernke, M. T., Braun, R. K., Meyer, K. C., and Funk, W. E. (2019). Direct human health risks of increased atmospheric carbon dioxide. Nat. Sustain. 2, 691-701. doi: 10.1038/s41893-019-0323-1

Keesing, F., Belden, L. K., Daszak, P., Dobson, A., Harvell, C. D., Holt, R. D., et al. (2010). Impacts of biodiversity on the emergence and transmission of infectious diseases. Nature 468, 647-652. doi: 10.1038/nature09575

Kharas, H., and Hamel, K. (2018). A Global Tipping Point: Half the World Now is Middle Class or Wealthier. Available online at: brookings.edu/blog/futuredevelopment/2018/09/27/a-global-tipping-point-half-the-world-is-nowmiddle-class-or-wealthier (accessed December 28, 2020).

King, A. (2016). Science, politics and policymaking. EMBO. Rep. 17, 1510-1512. doi: 10.15252/embr.201643381

Klare, M. T. (2001). Resource Wars: The New Landscape of Global Conflict. New York, NY: Henry Holt.

Klare, M. T. (2012). The Race for What's Left: The Global Scramble for the World's Last Resources. New York, NY: Metropolitan Books.

Klare, M. T. (2020, January 13). How rising temperatures increase the likelihood of nuclear war. The Nation.

Krumhansl, K. A., Okamoto, D. K., Rassweiler, A., Novak, M., Bolton, J. J., Cavanaugh, K. C., et al. (2016). Global patterns of kelp forest change over the past half-century. Proc. Natl. Acad. Sci. U.S.A. 113, 13785-13790. doi: $10.1073 /$ pnas. 1606102113

Kus, B. (2016). Wealth inequality: historical trends and cross-national differences. Sociol. Compass 10, 518-529. doi: 10.1111/soc4.12378

Lal, R. (2008). Carbon sequestration. Phil. Trans. R. Soc. B 363, 815-830. doi: $10.1098 /$ rstb.2007.2185

Lal, R. (2015). Restoring soil quality to mitigate soil degradation. Sustainability 7 , 5875-5895. doi: 10.3390/su7055875

Lamkin, M., and Miller, A. I. (2016). On the challenge of comparing contemporary and deep-time biological-extinction rates. BioScience 66, 785-789. doi: 10.1093/biosci/biw088

Legagneux, P., Casajus, N., Cazelles, K., Chevallier, C., Chevrinais, M., Guéry, L., et al. (2018). Our house is burning: discrepancy in climate change vs. biodiversity coverage in the media as compared to scientific literature. Front. Ecol. Evol. 5:175. doi: 10.3389/fevo.2017.00175

Leung, B., Hargreaves, A. L., Greenberg, D. A., McGill, B., Dornelas, M., and Freeman, R. (2020). Clustered versus catastrophic global vertebrate declines. Nature 588, 267-271. doi: 10.1038/s41586-020-2920-6

Levin, S. (1999). Fragile Dominion. Cambridge: Perseus Publishing.

Levy, L., and Herzog, A. N. (1974). Effects of population density and crowding on health and social adaptation in the Netherlands. J. Health Soc. Behav. 15, 228-240. doi: 10.2307/2137023

Lin, D., Hanscom, L., Murthy, A., Galli, A., Evans, M., Neill, E., et al. (2018). Ecological footprint accounting for countries: updates and results of the National Footprint Accounts, 2012-2018. Resources 7:58. doi: 10.3390/resources7030058

Lyons, K. (2020, 13 January 20). Climate refugees can't be returned home, says landmark UN human rights ruling. The Guardian.

Mayer, J. (2016). Dark Money: The Hidden History of the Billionaires Behind the Rise of the Radical Right. New York, NY: Anchor.

McLeman, R. (2019). International migration and climate adaptation in an era of hardening borders. Nat. Clim. Change 9, 911-918. doi: 10.1038/s41558-019-0634-2

Messerli, P., Kim, E. M., Lutz, W., Moatti, J.-P., Richardson, K., Saidam, M., et al. (2019). Expansion of sustainability science needed for the SDGs. Nat. Sustain. 2, 892-894. doi: 10.1038/s41893-019-0394-z

Mora, C., Dousset, B., Caldwell, I. R., Powell, F. E., Geronimo, R. C., Bielecki, Coral, R., et al. (2017). Global risk of deadly heat. Nat. Clim. Change 7, 501-506. doi: 10.1038/nclimate3322

Mora, C., Tittensor, D. P., Adl, S., Simpson, A. G. B., and Worm, B. (2011). How many species are there on Earth and in the ocean? PLoS Biol. 9:e1001127. doi: 10.1371/journal.pbio.1001127 
Nature (2018). Brazil's new president adds to global threat to science. Nature 563, 5-6. doi: 10.1038/d41586-018-07236-w

Nature Climate Change (2019). From migration to mobility. Nat. Clim. Change 9:895. doi: 10.1038/s41558-019-0657-8

Nyström, M., Jouffray, J. B., Norström, A. V., Crona, B., Søgaard Jørgensen, P., Carpenter, S. R., et al. (2019). Anatomy and resilience of the global production ecosystem. Nature 575, 98-108. doi: 10.1038/s41586-019-1712-3

Oreskes, N., and Conway, E. M. (2010). Merchants of Doubt. New York, NY: Bloomsbury Press.

Parks, R. M., Bennett, J. E., Tamura-Wicks, H., Kontis, V., Toumi, R., Danaei, G., et al. (2020). Anomalously warm temperatures are associated with increased injury deaths. Nat. Med. 26, 65-70. doi: 10.1038/s41591-019-0721-y

Patz, J. A., Campbell-Lendrum, D., Holloway, T., and Foley, J. A. (2005). Impact of regional climate change on human health. Nature 438, 310-317. doi: $10.1038 /$ nature 04188

Peng, B., Williams, S., Loughnan, M., Lloyd, G., Hansen, A., Kjellstrom, T., et al. (2011). The effects of extreme heat on human mortality and morbidity in Australia: implications for public health. Asia Pac. J. Publ. Health 23, 27S-36S. doi: $10.1177 / 1010539510391644$

Piketty, T. (2020). Capital and Ideology. Harvard, IL: Harvard University Press.

Pimm, S. L., Jenkins, C. N., Abell, R., Brooks, T. M., Gittleman, J. L., Joppa, L. N., et al. (2014). The biodiversity of species and their rates of extinction, distribution, and protection. Science 344:1246752. doi: $10.1126 /$ science. 1246752

Potts, S. G., Imperatriz-Fonseca, V., Ngo, H. T., Aizen, M. A., Biesmeijer, J. C., Breeze, T. D., et al. (2016). Safeguarding pollinators and their values to human well-being. Nature 540, 220-229. doi: 10.1038/nature20588

Pyke, G. H. (2017). Sustainability for humanity: it's time to preach beyond the converted. Trends Ecol. Evol. 32, 391-394. doi: 10.1016/j.tree.2017.03.010

Rees, W. E. (2020). Ecological economics for humanity's plague phase. Ecol. Econ. 169:106519. doi: 10.1016/j.ecolecon.2019.106519

Ripple, W. J., Smith, P., Haberl, H., Montzka, S. A., McAlpine, C., and Boucher, D. H. (2014). Ruminants, climate change and climate policy. Nat. Clim. Change 4, 2-5. doi: 10.1038/nclimate2081

Ripple, W. J., Wolf, C., Newsome, T. M., Barnard, P., and Moomaw, W. R. (2020). World scientists' warning of a climate emergency. BioScience 70, 8-12. doi: 10.1093/biosci/biz152

Ripple, W. J., Wolf, C., Newsome, T. M., Galetti, M., Alamgir, M., Crist, E., et al. (2017). World scientists' warning to humanity: a second notice. BioScience 67, 1026-1028. doi: 10.1093/biosci/bix125

Roe, D., Dickman, A., Kock, R., Milner-Gulland, E. J., Rihoy, E., and 't SasRolfes, M. (2020). Beyond banning wildlife trade: COVID-19, conservation and development. World Dev. 136:105121. doi: 10.1016/j.worlddev.2020.105121

Rogelj, J., den Elzen, M., Höhne, N., Fransen, T., Fekete, H., Winkler, H., et al. (2016). Paris Agreement climate proposals need a boost to keep warming well below $2{ }^{\circ}$ C. Nature 534, 631-639. doi: 10.1038/nature 18307

Schmeller, D. S., Courchamp, F., and Killeen, G. (2020). Biodiversity loss, emerging pathogens and human health risks. Biodivers. Conserv. 29, 3095-3102. doi: 10.1007/s10531-020-02021-6

Schmidhuber, J., and Tubiello, F. N. (2007). Global food security under climate change. Proc. Natl. Acad. Sci. U.S.A. 104, 19703-19708. doi: 10.1073/pnas.0701976104

Secretariat of the Convention on Biological Diversity (2020). Global Biodiversity Outlook 5. Montreal, QC: Secretariat of the Convention on Biological Diversity.

Selby, D. (2006). The catalyst that is sustainability: bringing permeability to disciplinary boundaries. Planet 17, 57-59. doi: 10.11120/plan.2006. 00170057

Serdeczny, O., Adams, S., Baarsch, F., Coumou, D., Robinson, A., Hare, W., et al. (2017). Climate change impacts in Sub-Saharan Africa: from physical changes to their social repercussions. Region. Environ. Change 17, 1585-1600. doi: 10.1007/s10113-015-0910-2

Shanley, P., and López, C. (2009). Out of the loop: why research rarely reaches policy makers and the public and what can be done. Biotropica 41, 535-544. doi: 10.1111/j.1744-7429.2009.00561.x

Sippel, S., Meinshausen, N., Fischer, E. M., Székely, E., and Knutti, R. (2020). Climate change now detectable from any single day of weather at global scale. Nat. Clim. Change 10, 35-41. doi: 10.1038/s41558-019-0666-7
Smith, K. R., Woodward, A., Lemke, B., Otto, M., Chang, C. J., Mance, A. A., et al. (2016). The last summer Olympics? Climate change, health, and work outdoors. Lancet 388, 642-644. doi: 10.1016/S0140-6736(16)31335-6

Smith, P., Ashmore, M. R., Black, H. I. J., Burgess, P. J., Evans, C. D., Quine, T. A., et al. (2013). The role of ecosystems and their management in regulating climate, and soil, water and air quality. J. Appl. Ecol. 50, 812-829. doi: 10.1111/1365-2664.1 2016

Sodhi, N. S., Brook, B. W., and Bradshaw, C. J. A. (2009). "Causes and consequences of species extinctions," in The Princeton Guide to Ecology, ed. S.A. Levin (Princeton, NJ: Princeton University Press), 514-520 doi: $10.1515 / 9781400833023.514$

Steffen, W., Rockström, J., Richardson, K., Lenton, T. M., Folke, C., Liverman, D., et al. (2018). Trajectories of the Earth system in the Anthropocene. Proc. Natl. Acad. Sci. U.S.A. 115, 8252-8259. doi: 10.1073/pnas.1810141115

Strona, G., and Bradshaw, C. J. A. (2018). Co-extinctions annihilate planetary life during extreme environmental change. Sci. Rep. 8:16724. doi: 10.1038/s41598-018-35068-1

Swan, S., and Colino, S. (2021). Count Down: How Our Modern World Is Threatening Sperm Counts, Altering Male and Female Reproductive Development, and Imperiling the Future of the Human Race. New York, NY: Scribner.

Tedesco, P. A., Bigorne, R., Bogan, A. E., Giam, X., Jézéquel, C., and Hugueny, B. (2014). Estimating how many undescribed species have gone extinct. Conserv. Biol. 28, 1360-1370. doi: 10.1111/cobi.12285

Tir, J., and Diehl, P. F. (1998). Demographic pressure and interstate conflict: linking population growth and density to militarized disputes and wars, 193089. J. Peace Res. 35, 319-339. doi: 10.1177/0022343398035003004

Toon, O., Robock, A., Turco, R. P., Bardeen, C., Oman, L., and Stenchikov, G. (2007). Consequences of regional-scale nuclear conflicts. Science 315, 1224-1225. doi: 10.1126/science,.1137747

United Nations (2016). The Paris Agreement. Paris: United Nations Framework Convention on Climate Change.

United Nations University (2015). 5 Facts on Climate Migrants [Online]. Institute for Environment and Human Security. Available online at: ehs.unu.edu/blog/5facts/5-facts-on-climate-migrants.html (accessed January 13, 2020).

Urban, M. C. (2015). Accelerating extinction risk from climate change. Science 348, 571-573. doi: 10.1126/science.aaa4984

U. S. House of Representatives (2019). Recognizing the Duty of the Federal Government to Create a Green New Deal [Online]. Washington, DC: 116th United States Congress. Available online at: congress.gov/bill/116th-congress/ house-resolution/109/text (accessed December 28, 2020).

Van Bavel, J. J., Baicker, K., Boggio, P. S., Capraro, V., Cichocka, A., Cikara, M., et al. (2020). Using social and behavioural science to support COVID-19 pandemic response. Nat. Hum. Behav. 4, 460-471. doi: 10.1038/s41562-020-0884-z

van Klink, R., Bowler, D. E., Gongalsky, K. B., Swengel, A. B., Gentile, A., and Chase, J. M. (2020). Meta-analysis reveals declines in terrestrial but increases in freshwater insect abundances. Science 368, 417-420. doi: 10.1126/science.aax 9931

Verdin, J., Funk, C., Senay, G., and Choularton, R. (2005). Climate science and famine early warning. Phil. Trans. R. Soc. B. 360, 2155-2168. doi: $10.1098 /$ rstb.2005.1754

Vethaak, A. D., and Leslie, H. A. (2016). Plastic debris is a human health issue. Environ. Sci. Technol. 50, 6825-6826. doi: 10.1021/acs.est.6b02569

Vollset, S. E., Goren, E., Yuan, C.-W., Cao, J., Smith, A. E., Hsiao, T., et al. (2020). Fertility, mortality, migration, and population scenarios for 195 countries and territories from 2017 to 2100: a forecasting analysis for the Global Burden of Disease Study. Lancet 396, 1285-1306. doi: 10.1016/S0140-6736(20)30677-2

Wackernagel, M., Hanscom, L., and Lin, D. (2017). Making the sustainable development goals consistent with sustainability. Front. Energ. Res. 5:18. doi: 10.3389/fenrg.2017.00018

Wackernagel, M., Lin, D., Evans, M., Hanscom, L., and Raven, P. (2019). Defying the footprint oracle: implications of country resource trends. Sustainability 11 , 2164-2164. doi: 10.3390/su11072164

Wagner, D. L. (2020). Insect declines in the Anthropocene. Annu. Rev. Entomol. 65, 457-480. doi: 10.1146/annurev-ento-011019-025151 
Waycott, M., Duarte, C. M., Carruthers, T. J. B., Orth, R. J., Dennison, W. C., Olyarnik, S., et al. (2009). Accelerating loss of seagrasses across the globe threatens coastal ecosystems. Proc. Natl. Acad. Sci. U.S.A. 106, 12377-12381. doi: 10.1073/pnas.0905620106

Webb, T. J., and Mindel, B. L. (2015). Global patterns of extinction risk in marine and non-marine systems. Curr. Biol. 25, 506-511. doi: 10.1016/j.cub.2014.12.023

White, R. (2017). Criminological perspectives on climate change, violence and ecocide. Curr. Clim. Change Rep. 3, 243-251. doi: 10.1007/s40641-017-0075-9

White, R. (2019). "Theoretical perspectives on environmental violence," in The Routledge International Handbook of Violence Studies, eds. W. DeKeseredy, C. Rennison, and A. Hall-Sanchez (London: Routledge), 121-134 doi: 10.4324/9781315270265-12

Wiedmann, T., Lenzen, M., Keyßer, L. T., and Steinberger, J. K. (2020). Scientists' warning on affluence. Nat. Comm. 11:3107. doi: 10.1038/s41467-020-16941-y

World Economic Forum (2020). Global Risks Report. 15th Edition. Geneva: World Economic Forum.
WWF (2020). Living Planet Report 2020. Gland: WWF.

Wynes, S., and Nicholas, K. A. (2017). The climate mitigation gap: education and government recommendations miss the most effective individual actions. Environ. Res. Lett. 12:074024. doi: 10.1088/1748-9326/aa7541

Conflict of Interest: The authors declare that the research was conducted in the absence of any commercial or financial relationships that could be construed as a potential conflict of interest.

Copyright (๑) 2021 Bradshaw, Ehrlich, Beattie, Ceballos, Crist, Diamond, Dirzo, Ehrlich, Harte, Harte, Pyke, Raven, Ripple, Saltré, Turnbull, Wackernagel and Blumstein. This is an open-access article distributed under the terms of the Creative Commons Attribution License (CC BY). The use, distribution or reproduction in other forums is permitted, provided the original author(s) and the copyright owner(s) are credited and that the original publication in this journal is cited, in accordance with accepted academic practice. No use, distribution or reproduction is permitted which does not comply with these terms. 